Debreceni Jogi Múhely 2019. (XVI.) 1-2.

Debreceni Egyetem, Állam- és Jogtudományi Kar, Polgári Jogi Tanszék, Debrecen

(University of Debrecen, Faculty of Law, Department of Civil Law, Debrecen)

DOI 10.24169/DJM/2019/1-2/2

\author{
Darai Péter \\ hatósági fellebbviteli szakereferens, kamarai jogtanácsos \\ NAV Fellebbviteli Igazgatósága, Ész̨ak-magyarországi Hatósági Föosztály
}

\title{
A FEDEZETI ELV ÉS A BECSÉRTÉK AZ ADÓVÉGREHAJTÁS RENDSZERÉBEN
}

Debreceni Jogi Múhely, 2019. évi (XVI. évfolyam) 1-2. szám (2019. július 20.)

DOI 10.24169/DJM/2019/1-2/2

The principles of property value and the appraised value in the system of the tax debt execution proceeding Summary

In my essay I'm trying to answer some questions in the topic of the appraisal of real property. During my work in National Tax and Customs Administration of Hungary - I daily meet the problem that the process of appraisal is very complex activity because of many internal and external factors. It needs great attention because the appraised value influences the execution of movable and immovable property and determines the purchase price in compulsory auctions. With this in mind it effects on refundation of tax debt. It is important to note at the same time that the target of the execution is not the recovery of the debt at any cost; at least essential guaranteed procedures which protect the rights of the debtors. In the following lines I focus the operative legislation of the tax execution proceeding and I describe the concerning judicial precedent with particular attention te case law of the Supreme Court. The importance of the subject presented by some decisions of the Constitutional Court. In my opinion without exaggeration the theme is so interesting the recently changed legislation cannot be connected to it because in theory anyone can get into a life situation that execution proceeding so it is worth knowing some rules about it.

\section{Bevezető gondolatok}

„A végrehajtás foganatosítása egyet jelent az állami kényszer tényleges alkalmazásával, e kényszert a végrehajtási eljárás sajátos szereplőjének, a bírósági végrehajtónak az eljárása testesíti meg. Az állami kényszer elsősorban vagyoni jellegủ hátrány, amelyet a végrehajtás foganatosításának szakaszában a bírósági végrehajtó alkalmazhat. A végrehajtás foganatosítása konkrét végrehajtási cselekmények útján „elevenedik meg”, amelyek az eljárásjogi szabályok helytelen alkalmazása folytán törvénynek nem megfelelő állapotot idézhetnek elő."1 Fenti sorok lényegre törően jellemzik a végrehajtási eljárás mibenlétét, amely - értelemszerúen - az adóeljárás záró szakaszára, az adóvégrehajtásra is érvényes. Utóbbi az adótartozás önkéntes megfizetésének elmaradása okán induló kényszerítő eljárás, amely - a költségvetési érdekek védelme érdekében - nemcsak lehetőség, hanem egyszersmind kötelezettség is az adóhatóság számára. Az adóhatóság által foganatosítandó végrehajtási eljárásokról szóló 2017. évi CLIII. törvény (a továbbiakban: Avt.) hatályba lépésével a jogalkotó továbbra is szem előtt tartja a koncepciót, miszerint a jogállamiság megköveteli, hogy a törvények és a bírósági ítéletek (hatósági határozatok) végrehajthatóságába vetett közbizalom megszilárduljon, tekintettel arra, hogy a kikényszeríthetetlen döntések ezzel ellentétesen hatnak. A jogbiztonság elvéből fakad az eredményes, észszerú időn belüli végrehajtás igénye.2 A jogállamiság egyik alapkövetelménye, hogy a közhatalmi szervek a jogszabályok által biztosított keretek között, megismerhető és kiszámítható módon fejtik ki tevékenységüket.3 Ez vonatkozik az adóvégrehajtásra is; a szabályozás csak abban az esetben tölti ki az alkotmányosság biztosította kereteket, ha az -

\footnotetext{
${ }^{1}$ Juhász Eszter: A végrehajtási kifogás új szabályainak margójára. Jog-Állam-Politika 2012/3. 131-142., 131.

2 A bírósági végrehajtásról szóló 1994. évi LIII. törvény 34/A. 『-a alkotmányellenességének vizsgálatáról szóló 1252/B/2010. AB határozat; az adózás rendjéről szóló 2003. évi XCII. törvény 152. \ (1) bekezdése „a végrehajtható okirat csatolása nélkül” szövegrésze alaptörvény-ellenességének megállapítására és megsemmisítésére irányuló indítvány elutasításáról szóló 22/2013. (VII.19.) AB határozat.

3 56/1991. (XI.8.) AB határozat.
} 
Debreceni Jogi Múhely 2019. (XVI.) 1-2.

Debreceni Egyetem, Állam- és Jogtudományi Kar, Polgári Jogi Tanszék, Debrecen

(University of Debrecen, Faculty of Law, Department of Civil Law, Debrecen)

DOI 10.24169/DJM/2019/1-2/2

a kellő egyensúly biztosítása mellett - az adós és a végrehajtást kérő érdekeit egyaránt figyelembe veszi. A téma kényes azon szempontból is, hogy a tárgyi eljárásban alkalmazott intézkedések a tulajdonjogot is korlátozzák, mely alapjogi kérdéseket is felvethet. Az Alkotmánybíróság több döntésében is hangsúlyozta, hogy a tulajdonjog valamely tartalmi elemének korlátozása akkor alkotmányellenes, amennyiben az nem valamely elkerülhetetlen, kényszerítő ok nélkül történik. Előfordulhatnak azonban olyan esetek is, amikor a korlátozás súlya az elérni kívánt célhoz viszonyítottan már aránytalan4; mindez - kellő gondosság mellett lefolytatott eljárási cselekmények hiányában - realizálódhat az adóeljárás legvégső szakaszában is. Tanulmányomban a fedezeti elv adóvégrehajtásban való érvényesülésének ismertetésére vállalkozom, összefüggésben a végrehajtási eljárás alá vont vagyon becsértéke megállapításának problematikájával. A dolgozatom premisszája a becsérték és a fedezeti elv közötti szoros - mi több, véleményem szerint szükségszerú - kapcsolat. Jóllehet a fedezet inkább közgazdasági fogalomnak tekinthetô szemben a becsérték jogi definíciójával, a kettô nem függetleníthető azon érvelés alapján, miszerint a kényszerértékesítés mechanizmusa a normál piaci viszonyoktól merőben eltérő. A foglalás sorrendjét és mértékét ugyanis pont a fedezeti elv érvényesülése határozza meg, amely a kényszerértékesítés specialitására tekintettel a becsértéknek a valós forgalmi értékhez történő közelítését igényli.

\section{A becsérték és a fedezeti elv kapcsolata - általánosságban}

Jóllehet a végrehajtási cselekmények sorrendjét, időpontját az adóhatóság e törvény által szabott keretek között maga határozza meg azzal, hogy a végrehajtási cselekmények közül azokat kell foganatosítani, amelyekkel a leghatékonyabban érhető el a végrehajtás célja, ugyanakkor az adósra nézve - az arányosság elvének figyelembevételével - a legkisebb mértékű korlátozással jár [Avt. 5-6. \$-ai]. A jogszabály tehát kiemelt jelentőséget tulajdonít az arányosság és fokozatosság elvének; vagyis csak a szükséges mértékú hatósági kényszer kerüljön alkalmazásra, az kisebb hátránytól haladjon a „komolyabb” cselekmény irányába5. Ugyanakkor - és a kérdéskör neuralgikus pontja itt keresendő - a gyakorlati szempontok figyelembe vétele legalább ennyire szükségelteti az eljárás gyors lefolytatását is. Ez az igény jellemzően a vagyonfeltárás eredményes volta esetén ütközik ki; amikor még kellő alappal feltételezhető, hogy az adós vagyona - legalábbis részben - a tartozás fedezetéül szolgálhat. Általánosságban kijelenthető, hogy a párhuzamos végrehajtási cselekmények alkalmazását - azon túl, hogy nem tekinthető contra legem eljárásnak - az eredmény centrikusság, és a hátralék összege egyes esetekben kifejezetten igazolja. Véleményem szerint az adóvégrehajtás során elsődlegesen a gyorsaságnak - a minél hamarabb történő térülésnek - kell érvényesülnie, hiszen egyrészt a költségvetés érdekei ezt a célt igénylik, másrészt elkerülendő, hogy adós hosszú, bizonytalan ideig álljon a végrehajtás fenyegetettsége és az eljárás hatálya alatt. A végrehajtási cselekmények „halmozódása” egyébiránt az adósra is különös pressziót jelenthet és akár a tartozás teljes összegének megfizetésére is ösztönzőleg hat; a gyakorlatban ugyanis az adóvégrehajtást nem feltétlenül a teljesítésre való képtelenség, hanem a teljesítésre való hajlandóság hiánya is legalább annyira indukálja.

\subsection{Ingóság és gépjármú foglalása}

A megállapítás különösen igaz az Avt. 3. \-a szerint az adóigazgatási rendtartásról szóló 2017. évi CLI. törvény (a továbbiakban: Air.) és az adózás rendjérốl szóló 2017. évi CL. törvény (a továbbiakban: Art.) eltérô rendelkezése hiányában mögöttes szabályként alkalmazandó bírósági végrehajtásról szóló 1994. évi LIII. törvény (a továbbiakban: Vht.) ismeretében. Ha az adós a végrehajtható okiratban feltüntetett kötelezettségét önként nem teljesítette, a végrehajtó az adós ingóságait foglalási jegyzókönyvben összeírja, és ilyen módon lefoglalja [Vht. 84. $\int(1)$ bekezdése]. Ez esetben az elidegenítési és terhelési tilalom rögtön beáll6, a vagyontárgy lefoglalása után kötött adásvételi szerződés már érvénytelen, az a foglalás hatálya alóli feloldásra kellő alapot nem teremt.7 Több

\footnotetext{
4 7/1991. (II.28.) AB határozat, 11/1993. (II.27.) AB határozat.

5 A bírósági végrehajtásról szóló 1994. évi LIII. törvény 6. (1) bekezdése alkotmányellenességének vizsgálatáról szóló 539/D/2005. AB határozat. Amennyiben a tartozás nem olyan nagyságrendű, amely eleve kizárja azt, hogy egyéb vagyonból is behajtható, akkor az ingatlan árverésre bocsátása nem indokolható; különösen nem abban az esetben, ha

a végrehajtó az adóst nem találja otthon, és csupán fizetési felhívást hagy a helyszínen, de újabb foglalást nem kísérel meg, és az adós egyéb teljesítési lehetőségeit sem ellenőrzi [Legfelsőbb Bíróság (Kúria) Pfv.I.20.212/1999.].

${ }^{6}$ Legfelsőbb Bíróság (Kúria) Pfv.I.21.372/2005. A foglaláshoz kötött elidegenítési és terhelési tilalom vonatkozik a részvényre (Fővárosi Îtélőtábla 16.Cgf.43.336/2006.), és az üzletrészre (Fővárosi Îtélőtábla 13.Cgf.47.070/2018/2.) is.

${ }^{7}$ Legfelsőbb Bíróság (Kúria) Pfv.I.22.365/1999. A polgári perrendtartásról szóló 2016. évi CXXX. törvény 538. \(1) bekezdése szerint keresettel kérheti a lefoglalt vagyontárgy foglalás alóli feloldását az, aki a lefoglalt vagyontárgyra a
} 
Debreceni Jogi Múhely 2019. (XVI.) 1-2.

Debreceni Egyetem, Állam- és Jogtudományi Kar, Polgári Jogi Tanszék, Debrecen

(University of Debrecen, Faculty of Law, Department of Civil Law, Debrecen)

DOI 10.24169/DJM/2019/1-2/2

ingóság lefoglalása esetén a foglalási sorrendet a végrehajtó állapítja meg [Vht. 87. \(1) bekezdése]. Ez azért releváns, mert amennyiben egy későbbi árverés alkalmával az adós érdemben nem él a kényszerértékesítés sorrendjét meghatározó jogosultságával [Avt. 65. \(1) bekezdése], akkor - függetlenül a foglalással érintett vagyontárgyak értékétől és piacképességétől - a foglalási jegyzőkönyvben feltüntetett foglalási sorrend lesz az irányadó; vagyis elképzelhetô, hogy a tartozás kiegyenlítésére több, kisebb értékkel bíró vagyontárgy árverezésére lesz szükség annak ellenére, hogy a térülés elvben egyetlen, magasabb forgalmi értékkel rendelkező vagyonelem értékesítésével is biztosítható. Másrészt a végrehajtó a foglalást addig folytatja, amíg a követelés - járulékaival együtt, ideértve az eljárás befejezéséig előreláthatóan felmerülő végrehajtási költséget - nincs teljesen fedezve [Vht. 87. \ (2) bekezdése].8 Ezen rendelkezés kapcsán válik egyértelművé jelen tanulmány premisszája, miszerint a becsérték és a fedezeti elv között szoros kapcsolat lelhető fel. A foglalásnak ugyanis szükségszerú eleme a vagyontárgy becsértékének meghatározása.

A végrehajtó a foglaláskor becsléssel megállapítja a lefoglalt ingóság értékét. A becsérték megállapításánál a végrehajtó a forgalmi árat veszi alapul. Ha a felek a becsértékben megegyeztek, ez az irányadó [Vht. 97. \(1)-(2) bekezdései]. Az Avt. 8. \ (2) bekezdése a jegyzőkönyvek - általános jegyzőkönyv, foglalási jegyzőkönyv, árverési jegyzőkönyv - általános tartalmát rögzíti9, a Vht. pedig speciális rendelkezést tartalmaz a foglalási jegyzőkönyvre az általános formai és tartalmi jellemzőkön túlmenően.10 Figyelemmel arra, hogy a foglalási jegyzőkönyvnek tartalmaznia kell a tartozás jogcímét, valamint összegét, és tekintettel a Vht. 87. \(2) bekezdésére - mely a foglalási cselekmények mértékét a tartozáshoz „igazítja” - a foglalási jegyzőkönyvből ki kell derülnie a tartozás, és a lefoglalt vagyontárgyak együttes becsértéke egymáshoz viszonyított arányának, vagyis a becsérték foglalási jegyzőkönyvben való feltüntetése - annak ellenére, hogy azt sem az Avt., sem pedig a Vht. nem írja elő - nem mellőzhető. A jegyzőkönyv azonosításra alkalmas módon kell, hogy tartalmazza az érintett ingók megnevezését, darabszámát, márkajelzését, és egyéb egyedi jellemzőit is; azok pontos körülírása egy későbbi árverés eredményes lefolytatása érdekében mind az adós, mind az adóhatóság érdekeit szolgálja.

Jóllehet a gépjármúvek kapcsán is van lehetőség helyszíni eljárás során történő foglalásra, ezen vagyontárgyak végrehajtás alá vonása jellemzően adminisztratív módon - a gépjármú-nyilvántartás adatai alapján - történik.11.

tulajdonjoga vagy más olyan joga alapján tart igényt, amely akadálya a bírósági, közigazgatási vagy adóvégrehajtás során történő értékesítésnek. Az igényper megindításának a ténye - a későbbi pernyertesség kérdésétől függetlenül - a végrehajtás alá vont vagyontárgy értékesítése szempontjából is jelentőséggel bír [Avt. 58-59. \-ai].

${ }^{8}$ Lefoglalni az adós birtokában, ơrizetében levő vagy más olyan ingóságot lehet, amelyről valószínűsíthető, hogy az adós tulajdonában van. Nem lehet lefoglalni az adós birtokában, őrizetében levő ingóságot, ha a rajta levő jelből vagy más körülményből minden bizonyítás nélkül kétségtelenül megállapítható, hogy az ingóság nincs az adós tulajdonában [Vht. 86. \$ (1)-(2) bekezdései]. A vizsgálata tehát a birtok tényének fennállására terjed ki. Osztom Schadl György alábi megállapítását, miszerint „... a birtoklás ténykérdés, a birtok fogalmi elemei (corpus a ténylegesség és az animus a birtoklásra irányuló akarat) közül a végrehajtónak a ténylegességet, vagyis az ingóság adósnál fellelhető, illetve az adós őrizetében lévő tényét kell vizsgálnia. Nyilvánvaló, hogy ha csak akkor foglalhatna a végrehajtó, ha az adós megerősíti a birtoklásra irányuló akaratát, akkor drasztikusan visszaesne az ingófoglalások száma ...A valószínúsítés nem bizonyítás, hanem egy ahhoz sok szempontból hasonló tevékenység, amelynek nemcsak az eredménye nem lehet a meggyőzés (a mi esetünkben a végrehajtóé), hanem a célja sem: a valószínűsítés a bizonyosságnál jóval alacsonyabb szintet képviselő kategória, amely a végrehajtó meggyőzése helyett valamely tény vagy körülmény fennállásának (vagyis jelen esetben az ingóság adós tulajdonát képező mivoltának) hihetôvé tételére irányul.”. Schadl György: Az ingófoglalás alapvető szabályai a bírósági végrehajtás során. Polgári Szemle 2017/1-3. 83-93., 86.

${ }^{9}$ A jegyzőkönyvben minden esetben fel kell tüntetni a) az adós és a jelen levő más érdekelt nevét és lakóhelyét, természetes személyazonosító adatait, elnevezését, a bíróság által nyilvántartandó jogi személy nyilvántartási számát és székhelyét, valamint a végrehajtó azonosításához szükséges adatokat b) az eljárás helyét és idejét c) a végrehajtandó követelés jogcímét és összegét d) a behajtást kérő, illetve a behajtást kérő hatóság és az adóhatóság megnevezését, utóbbi hivatalos bélyegzőjét e) az eljárási cselekmény leírását és f) foglalási és árverési jegyzőkönyv esetén a Vht.-ban az adott típusú jegyzőkönyvre meghatározott egyéb adatokat és körülményeket.

10 A foglalási jegyzőkönyvben fel kell tüntetni az adós háztartásához tartozók számát, fel kell sorolni a végrehajtás alól mentesen hagyott vagyontárgyakat [Vht. 88. \(1) bekezdésének első mondata].

${ }^{11}$ Erre akkor kerülhet sor, ha az adós a jármú tulajdonosaként van a nyilvántartásba bejegyezve, illetve ennek hiányában is, ha a jármú a házastársi közös vagyonba tartozik. A végrehajtó a foglalási jegyzőkönyv másolatának megküldése mellett az elidegenítési és terhelési tilalom bejegyzése érdekében megkeresi a közlekedési igazgatási hatóságot. A hatóság köteles e felhívásnak haladéktalanul eleget tenni. Az adóhatóság a lefoglalt jármú forgalomból történő kivonása iránt legkésőbb az árverési hirdetmény kitűzésével egyidejűleg intézkedik [Avt. 47. \(1) bekezdése]. Meg kell jegyezni, hogy a forgalmi engedély bevonásánál eljáró közlekedésrendészeti hatóságot a végrehajtó megkeresése és a foglalási jegyzőkönyv tartalma is köti [Legfelsőbb Bíróság (Kúria) Kfv.II.39.070/2005.]. 
A nyilvántartásból történő foglalásnál rögzíteni kell a gépjármú típusát, forgalmi rendszámát, színét, gyártási évét, motorszámát, lényegében minden olyan adatot, amelyek elősegítik a vagyontárgy beazonosíthatóságát. A nyilvántartás alapján történő foglalás esetén a Vht. 97. \(1) bekezdésének érvényesülése korlátozott; a becsérték megállapítására jellemzően utólagos helyszíni eljárás keretei között, a gépjármú múszaki állapotának felmérése után kerül sor.12

Az ingóságok kapcsán tehát a becsérték meghatározása során elsődlegesen a felek megegyezése az irányadó, másodsorban pedig az adóvégrehajtó általi becsléssel való meghatározás. Figyelemmel kell lenni utóbbinál az ingóság beszerzésének (gyártásának) időpontjára, jellemző élettartamára, kihasználtságára, foglaláskori használhatóságára, az avulás, a használat, és a rendkívüli állagromlás miatti értékcsökkentő tényezőkre. Ez ellenben vice versa is igaz; fel kell mérni az állagmegóvásban, minőségben, felújitásban, esztétikai jellegzetességekben megjelenő értéknövelő faktorokat is.

\subsection{Ingatlan foglalása}

Némiképp összetettebb a helyzet az ingatlanok esetében. Amellett, hogy az egyéb vagyontárgyak lefoglalása is kihatással lehet az adós anyagi viszonyaira, a tulajdonjog körébe tartozó dolgok közül jellemzően az ingatlan képviseli a legnagyobb értéket. Erre tekintettel a törvényalkotó az ingatlan becsértékének minél pontosabb megállapítása érdekében az adóst érintően erősebb garanciákat is érvényesít, vagyis a becsérték meghatározására irányuló eljárás is kötöttebbnek tekinthető. Az adós tulajdonában levő ingatlant az ingatlan jellegére, múvelési ágára és az ingatlant terheló jogra vagy tilalomra, továbbá az ingatlanhoz kapcsolódó, az ingatlan-nyilvántartásba feljegyzett tényekre tekintet nélkül végrehajtás alá lehet vonni [Vht. 136. \(1) bekezdése]. Ez esetben az adóhatóság az ingatlan lefoglalása végett megkeresi az ingatlanügyi hatóságot, amely a végrehajtási jogot soron kívül bejegyzi az ingatlan-nyilvántartásba [Avt. 52. \(3) bekezdése]. Az ingóságok lefoglalásával ellentétben ez még nem jelent automatikusan elidegenítési és terhelési tilalmat; „csupán” azzal a következménnyel jár, hogy a bejegyzést követően csak olyan jog megszerzésének és nyilvántartásba bejegyzésének lehet helye, amely nem sérti a végrehajtást kérő jogát, illetve nem hiúsítja meg a végrehajtás célját sem.13 Az intézkedés adminisztratív jellege a birtokláshoz, hasznosításhoz való jogot érdemben nem, a rendelkezési jog gyakorlását pedig csak részben akadályozza.14

A foglalást követően a végrehajtó az ingatlan értékesítése előtt a 6 hónapnál nem régebbi adó- és értékbizonyítványt15 is figyelembe véve vagy - bármelyik fél erre irányuló kérelmére - igazságügyi szakértő szakvéleménye alapján megállapítja az ingatlan becsértékét mind a beköltözhető, mind pedig a lakott állapotban történő értékesítés esetére [Vht. 140. \(1) bekezdése]. Az adó- és értékbizonyítványnak, illetve az igazságügyi szakértő szakvéleményének tartalmaznia kell azt, hogy az ingatlan lakóingatlannak minősül-e. A jogszabályhely azon fordulatával, hogy a 6 hónapnál nem régebbi adó- és értékbizonyítványt is figyelembe véve kell megállapítani a becsértéket, közvetetten egyszersmind arra utal, hogy ilyen esetekben további eljárási cselekmények lefolytatására is szükség van. Ilyen intézkedést jelent a végrehajtással érintett ingatlan jegyzőkönyvezett - helyszíni bejárása, külső- és belső állapotfelmérése, ezen túlmenően az adóhatóságnak módjában áll a becsérték megállapítása végett a hivatali nyilvántartási adatok felhasználása is. Utóbbi úgy történik, hogy az adóhatóság a lefoglalt ingatlannal azonos rendeltetésú ingatlanok vagyonszerzési adataiból - a tulajdonosok személyazonosságának megállapítására alkalmatlan módon - esetenként változó mennyiségben az idő- és térbeli szúkítést elvégezve ingatlanokat von elemzési körbe, és azok becsérték meghatározása

\footnotetext{
12 A becsérték meghatározása során kiindulópontként szolgálhatnak egyes internetes oldalakon - www.hasznaltauto.hu, www.kocsi.hu - fellelhető információk, továbbá az Eurotax-katalógus is. Ezen adatokat a gépjármú tényleges műszaki állapotának felmérése után célszerû beszerezni; az egyedi paraméterek - a becsérték minél reálisabb meghatározása okán eleve behatárolják az adatbázis szűrési feltételei által meghatározott mozgásteret.

13 Legfelsőbb Bíróság (Kúria) Kfv.V.37.437/2000. A végrehajtási jog dologi hatályú jog, azaz mindenkivel szemben érvényes. Amennyiben tehát az adós, mint a végrehajtási joggal terhelt ingatlan tulajdonosa az ingatlant elidegeníti, az új tulajdonos - egy sikeresen lefolytatott árverés esetén - köteles tűrni az adóhatósági követelés kielégítését.

${ }^{14}$ Debreceni Ítélőtábla Pf.II.20.262/2008.

${ }_{15} \mathrm{Az}$ ingatlan fekvése szerint illetékes települési önkormányzat jegyzője által kiállított adó- és értékbizonyítvány tartalmazza az ingatlan és az ingatlanszerzők (tulajdonosok) adatait, az érték megállapításánál figyelembe vett tényezőket, továbbá az ingatlannak az adott időpontban fennálló forgalmi értékét. Az adó- és értékbizonyítvány kiállítására irányuló eljárásban az ügyintézési határidő 8 nap [az illetékekről szóló 1990. évi XCIII. törvény (a továbbiakban: Itv.) 101. 『-a]. Az adó- és értékbizonyítvány hatósági bizonyítvány, az közokiratnak minősül.
} 
Debreceni Jogi Múhely 2019. (XVI.) 1-2.

Debreceni Egyetem, Állam- és Jogtudományi Kar, Polgári Jogi Tanszék, Debrecen

(University of Debrecen, Faculty of Law, Department of Civil Law, Debrecen)

DOI 10.24169/DJM/2019/1-2/2

szempontjából releváns jellemzőit (múszaki állapot, funkcionális használat, közmúvesítettség, infrastruktúra, földrajzi-területi elhelyezkedés, épület-energetikai tulajdonságok, esztétikai érték) az adó- és értékbizonyítványban foglaltak ellenőrzésére kontrollként használja, figyelembe véve az értékcsökkentő vagy növelő tényezőket is.

Az ingatlan forgalmi értékének megállapítására a szakmai gyakorlat három metódust ismer. A legegyszerúbb a piaci összehasonlító adatelemzés módszere, ami konkrét adásvételi szerződésekben feltüntetett vételárak összemérésével történik, figyelemmel az ingatlan hasonló, vagy azonos fizikai tulajdonságaira. Ezen esetben az ingatlan és a felépítmény értékelése együttesen történik, azokat egységes egészként kell kezelni. A költségalapú (nettó pótlási) módszert jellemzően speciális rendeltetésű ingatlanoknál16 alkalmazzák. Ez az értékelési módszer az újraelőállítási költségét veszi kiindulási alapként, majd - figyelembe véve a rendeltetésszerủ használatot elősegítő karbantartást is - csökkenti a műszaki (fizikai), a funkcionális, valamint a gazdasági amortizáció értékével, ellenben értéknövelő tényezóként veszi figyelembe a felépítményhez tartozó földterület értékét. Végezetül a hozamszámításon (hozadéki értékelésen) alapuló módszer lényege, hogy az ingatlannal elérhető jövőbeli hasznok, és kiadások különbözete nettó jövedelemként képezi le az ingatlan piaci értékét a hasznosítás alternatíváira fókuszálva, elemezve a jövőbeli gazdasági-pénzügyi kockázatokat is. Nem kizárt azonban az egyik módszer alkalmazása mellett a másik két metódus kontrollként történő használata, mint ahogy lehetőség van a három módszer által meghatározott forgalmi értékek - akár súlyozott - átlagának képzésére és a becsérték ekkénti meghatározására is.

\subsection{A becsérték megállapitása az adóbatóság gyakorlatában}

Egyetértek azon megállapítással, hogy „...valami különös szakértelem a mindennapi foglalás tárgyát tevő dolgok becsléséhez nem kell; azt a végrehajtó is egészen jól elvégezheti, ha pedig olyan becslésrôl van szó, a mely szakértelmet igényel, akkor mind a mai törvény, mind a javaslat értelmében, úgy is lehet, sôt kell is szakértő becslőt alkalmazni...”.17 Az ingóságok vonatkozásában fentiek miatt az adóhatóság jellemzően a jellegüknél fogva relatíve könnyen értékesíthető vagyont (elektronikai cikkek, lakberendezési tárgyak stb.) vonja az adóvégrehajtás körébe, illetve amelynek a becsértéke - az előfordulási gyakoriságára figyelemmel - is viszonylag szűkebb kereteken belül, a keresleti-kínálati viszonyokkal hozzávetólegesen egyezően határozható meg. A becsérték szakértő-becsüs általi megállapításának lehetőségével - annak költségvonzatától függetlenül nyilvánvalóan akkor célszerű élni, amennyiben szabadpiaci összehasonlító érték az adott vagyontárgy kapcsán nem áll rendelkezésre, vagyis annak jellege szükségelteti a szakértelmet.18

Ingatlanok esetében a gyakorlat e körben is némiképp eltérő. Annak előrebocsátása mellett, hogy az Itv. hatálya értelemszerűen - nem terjed ki az adóvégrehajtásra, könnyen megállapítható, hogy az igazságügyi szakértők által alkalmazott becslési módszer, és az adóvégrehajtók által követett eljárási metódus merően eltérő. A szakértők az adott értékelési módszert ugyanis belátásuk szerint - értelemszerűen a szakma keretei között -, szabadon választják meg, addig az adóhatóság - az adó- és értékbizonyítványban foglaltakat figyelembe véve - jellemzően a piaci összehasonlító adatokon alapuló értékelést preferálja.19 Nehezen vitatható, hogy az adó- és értékbizonyítványon alapuló, és az összehasonlító forgalmi érték adatokat kontrollként felhasználó értékelés minimalizálja az eljárás költségeit, ellenben az adó- és értékbizonyítványban feltüntetett forgalmi érték a helyi települési szabályzat sajátosságait leképezve egy mechanikus, kvázi $\mathrm{Ft} / \mathrm{nm} 2$ fajlagos érték meghatározáson nyugszik, amely önmagában veti fel azon kérdést, hogy ezen értékelési mód alkalmas-e arra, hogy a forgalmi értékről - az árverési vételárban tükröződő értékbefolyásoló tényezőket figyelembe véve - akár becsérték szintjén is valós képet adjon. Ki kell jelenteni ellenben azt is, hogy a szakértők által alkalmazott értékelési módozatok és szempontok az ingatlan forgalmi értékének megállapításánál a piaci viszonyoknak megfelelố átlagos gazdasági

\footnotetext{
${ }^{16}$ Ezek olyan ingatlanok, melyek méretük, földrajzi elhelyezkedésük, az adott gazdasági szektorbeli sajátosságuk stb. miatt más ingatlannal nem hasonlíthatóak össze, illetőleg a más ingatlannal való összehasonlítás a végrehajtás alá vont, és értékelni kívánt ingatlan piaci értéke vonatkozásában egyértelmű torzulást okozna.

${ }^{17}$ Magyar Jogászegyleti értekezések/szerk: Dr. Szladits Károly (Dr. Márkus Dezső előadása, A végrehajtási törvény reformja, Budapest, Franklin társulat nyomdája, 1907.). Idézi Pataki János István: Gondolatok a bírósági végrehajtás rendszeréről. Jogelméleti Szemle 2013/1., 121-135., 133.

18 Arany, platina, ezüst lefoglalása [Vht. 98. \-a]; arany vagy platina felhasználásával készült tárgy, drágakő lefoglalása [Vht. 99. \ (1) bekezdése]; üzletrészfoglalás [Vht. 101. \ (1)-(2) bekezdései].

19 Az Itv. 69. S (3) bekezdése alapján az állami adóhatóság a forgalmi értéket elsősorban az összehasonlító értékadatok alapján állapítja meg, de - az összehasonlító értékadatok hiányában - más értékmeghatározó módszert (nettó pótlási költségalapú értékbecslés, hozamszámításon alapuló értékbecslés stb.) is alkalmazhat.
} 
Debreceni Jogi Múhely 2019. (XVI.) 1-2.

Debreceni Egyetem, Állam- és Jogtudományi Kar, Polgári Jogi Tanszék, Debrecen

(University of Debrecen, Faculty of Law, Department of Civil Law, Debrecen)

DOI 10.24169/DJM/2019/1-2/2

környezetet feltételeznek; ezeknek az adóhatóság által a becsérték meghatározása során való gyakorlati alkalmazhatósága - a kényszerértékesítés későbbiekben részletezésre kerülő sajátos mechanizmusa miatt - eleve kockázatot hordoz magában.

Másrészt utalni kell arra, hogy a szakértő kirendelése kizárólag szakkérdésben lehetséges, ebben az esetben viszont nem is mellőzhető. $20 \mathrm{Az}$ adóeljárás során akkor kell szakértőt meghallgatni vagy - legalább 15 napos határidő tűzésével - szakvéleményt kérni, ha az ügyben jelentős tény vagy egyéb körülmény megállapításához különleges szakértelem szükséges, és az eljáró adóhatóság nem rendelkezik megfelelő szakértelemmel [Air. 66. (1) bekezdése]. Azon jogtechnikai megoldásból, miszerint az adójogi normák nem írják elő kógens jelleggel a becsérték megállapításához szakértő bevonását, következik az is, hogy az adóhatóság a szakértő hivatalbóli kirendelésének lehetőségével ritkán él. Ez abban érhető tetten, hogy az adó- és értékbizonyítvány adattartalmának - közokirati jellege miatti - elfogadása az ingatlan felmérése mellett lehetôvé teszi az eljárás elhúzódásának megakadályozását. Ezen túlmenően pedig a szakszerű és hatékony eljárás elve magában foglalja a költségtakarékosságra irányultságot is [Air. 2. \$-a]. Az adóvégrehajtásban a „mindent az adós fizet” érvényesül;21 ezért nem szerencsés megoldás többletterhet hárítani adósra egy külön bizonyítással akkor, amikor azt adós nem is indítványozta, másrészt a foganatosításától sem feltétlenül várható olyan eredmény, mely a meghatározni kívánt becsértéket ab ovo cáfolná.22

Fenti kijelentés okán szükségesnek tartom vázlatosan bemutatni a hatóságot terhelő tényállás tisztázási kötelezettség tartalmát, amely nem függetleníthető a bizonyítékok értékelésére vonatkozó jogalkalmazói folyamattól sem. Az adóeljárás - törvényben meghatározott kivételektôl eltekintve - a szabad bizonyítás talaján áll; a jogalkotó a hatóságra bízza a bizonyítási eszközök megválasztását, az egyes bizonyítékok erejét illetően sem állít kötelezően alkalmazandó hierarchiát.23 A hatóság jogosult minősíteni azt, hogy az ügy eldöntése szempontjából mely tény bír jelentőséggel, mely bizonyítéknak milyen bizonyító erőt tulajdonít, azok erejét hogyan értékeli; ahogyan azt is, hogy a bizonyítás lefolytatása során milyen cselekményeket foganatosít. A tényállás felderítésének kötelezettsége a közhiedelemmel ellentétben korántsem parttalan; annak azokra a döntéshozatalhoz szükséges, releváns tényállási elemekre kell kiterjednie, amelyek alapján megítélhető a döntés jogszerűsége, valamint megalapozottsága.24 A bizonyítékok értékelésének logikai folyamata során az adóhatóság az egész bizonyítást „teszi mérlegre”, figyelemmel a bizonyítékok egymásra épülésére, összefüggéseire; egyetlen korlátja, hogy nem jelenthet önkényes értékítéletet. A tényállás és a bizonyítékok szoros kapcsolatban állnak egymással; a tényállás megállapítása, a bizonyítékok értékelése a jogalkalmazó hatásköre. A jogalkotót ugyanakkor széles körű mérlegelés illeti meg a bizonyítási rendszer kialakítása során, amelynek korlátja a tisztességes eljárás követelménye; a bizonyításra vonatkozó rendelkezések szoros összefüggést mutatnak a tisztességes eljáráshoz való jog Alaptörvényben rögzített követelményével.25 Ezen eszmefuttatástól nem tekinthettem el, hiszen az adóvégrehajtásra vonatkozó jogi környezet nem írja elő a szakértő becsérték megállapítása során való kötelező közreműködését - mint ahogyan a szakvélemény kógens jelleggel történő figyelembe vételét, és azzal megegyező tartalmú döntés meghozatalát sem -; ellenkező esetben a jogszabály a bizonyítékok szabad értékelésének jogát vonná el az adóhatóságtól.26

Jóllehet tehát a szabad bizonyítás rendszeréből következően a kirendelt szakértő szakvéleménye - főszabályként

20 A szakkérdés a ténykérdés egy típusa, és nem a tényekből levont jogkövetkeztetés része [Legfelsőbb Bíróság (Kúria) Kfv.III.37.054/2010.]. „A szakértőnek az a feladata, hogy a tudomány és a múszaki fejlődés eredményeinek felhasználásával készített szakvéleményével segítse a tényállás megállapítását és a szakkérdés eldöntését.” (419/E/2000. AB határozat).

${ }^{21} \mathrm{Az}$ adós - jogszabályban meghatározottak szerint - köteles a végrehajtással kapcsolatban felmerült valamennyi költség, így a készkiadás, a költségminimum és jogszabályban meghatározottak szerint a végrehajtási költségátalány megfizetésére [Avt. 11. $\int(1)$ bekezdése].

${ }^{22}$ Megfontolandó Kálmán János álláspontja, miszerint a szakkérdések megállapítása esetén a tisztességes ügyintézéshez való jog, mint a közigazgatási eljárás minősége akkor érvényesülhet, ha a jogi környezet a szakkérdés megválaszolását kifejezetten szakmai kompetenciával rendelkező személy (intézmény) feladatává teszi. Kálmán János: A szakkérdés vizsgálata a magyar közigazgatási hatósági eljárásjogban. Jogtudományi Közlöny 2018/2. 104-113., 111.

${ }^{23} \mathrm{Ha}$ a törvény eltérően nem rendelkezik, az adóhatóság szabadon választja meg a bizonyítás módját, és a rendelkezésre álló bizonyítékokat bizonyító erejüknek megfelelően értékeli [Air. 58. \(4) bekezdése].

${ }^{24}$ Kúria Kfv.III.35.103/2015/17., I.35.770/2016/9., I.35.270/2017.

25 7/2013. (III.1.) AB határozat, 3119/2016. (VI.21.) AB végzés, 3090/2019. (V.7.) AB határozat.

${ }^{26}$ Helyénvalóbb a bizonyítékok mérlegelése helyett a bizonyitékok értékelése megfogalmazás; a Kúria is utalt arra, hogy a tényállás megállapítása okán végzett bizonyíték értékelés - azok egyenkénti, és egymással történő egybevetése, az un. „,bizonyításos értékelés” - nem azonosítható a mérlegelési jogkörben hozott döntéssel (Kfv.V.35.789/2014/4.) 
Debreceni Jogi Múhely 2019. (XVI.) 1-2.

Debreceni Egyetem, Állam- és Jogtudományi Kar, Polgári Jogi Tanszék, Debrecen

(University of Debrecen, Faculty of Law, Department of Civil Law, Debrecen)

DOI 10.24169/DJM/2019/1-2/2

- nem kötelező a hatóságra, mindez azonban nem jelenti bizonyító erejét illetően annak elhanyagolhatóságát; mi több, a becsérték megállapítására irányuló eljárásban annak tartalma tipikusan érvényre jut.27 Ellenben fentiek abban az esetben érvényesek, amennyiben a szakvélemény aggálymentes, helyességéhez kétség nem fér, a bizonyított tényekkel nem áll ellentétben. Emellett a szakértő szakvéleménye csak azon a területen értékelhetô, melyen kompetenciával rendelkezik.28 A szakvélemény a bizonyítékok körében nem bír primus inter pares jelleggel; a szakszerűségi foka, és tudományos értéke az, ami meghatározza a bizonyítékok közötti ranghelyét.29 A szakvélemény csak egy bizonyítási eszköz, az nem eleve köti az adóhatóságot. Az ügyet nem a szakértő dönti el, ezért a jogalkalmazónak a szakvéleményen kívül az ügyben releváns egyéb bizonyítékokat is az értékelés körébe kell vonnia.30 Ha a szakértő belép az eljárásba, biztosítani szükséges adós számára azt, hogy nyilatkozattételi jogát gyakorolhassa, közvetlenül reagálhasson a bizonyítás eljárási mozzanataira, a keletkezett szakértői véleményre, mint bizonyítási eszközre.31

\section{A kényszerértékesítés specialitásai}

Bár általánosságban nem vitatható, hogy mind az adóhatóság, mind pedig az adós érdeke, hogy a becsérték magas összegben kerüljön megállapításra - vagyis a tartozásból minél nagyobb összeg térüljön meg -, hangsúlyozni kell azt is, hogy az eltúlzott becsérték az árverésen történő értékesítés lehetőségeit is erős korlátok közé kényszeríti. A szabadpiaci forgalmi érték32, valamint a becsérték ugyanis egymással nem szinonim fogalmak; előbbi egy „idealizált” ár, amennyiért valóságos (értsd: „steril”) piaci környezetben - feltételezve az eladási és vételi hajlandóságot, a kényszermentességet, az eladási szándék meghirdetésének nyilvánosságát, az adásvétel lebonyolítására rendelkezésre álló időtartam ésszerűségét - a vagyontárgy adásvételére sor kerülhetne. Az adóvégrehajtás során a vagyoni elemeket ellenben nem valós forgalmi értéken, hanem az árveréskor elérhető legmagasabb áron, az aktuális keresleti-kínálati viszonyok között értékesítik, vagyis elképzelhető - a gyakorlat szerint inkább ez a jellemző -, hogy egy vagyontárgy a forgalmi értékénél alacsonyabb áron kerül eladásra. A kényszerértékesítés ugyanis nem a normál értékesítési piacra jellemző körülményeket tükrözi, hiszen „,...a kényszereljárások piaca elképzelhetetlenül messze van a közgazdasági értelemben vett 'tökéletes piac'-tól, és olyan markáns sajátosságok, törvényszerűségek jellemzik, amelyek már önmagukban drasztikus mértékben torzítják az ideális körülmények között elérhető árat.”.33 A térülési mutató erős összefüggésben áll a kényszerértékesítésre kihatással bíró tényezőkkel: a) a vagyontárgy forgalmi árának negatív irányú torzulásával, amelyet a piac sajátosságai okoznak b) az eljárás költségvonzatával c) a kényszerértékesítésben részt vevő független harmadik személlyel, a végrehajtóval, akinek önálló érdekstruktúrája esetenként a térülési arányt is csökkentheti. Hitelezői aspektusból lényegében bármilyen más alternatíva (adósságrendezési megállapodás, követelés-eszköz konverzió, az adott tevékenységi kör múködtetésének adóstól való átvétele) kedvezőbb, a kényszerértékesítés tehát ultima ratio jelleggel alkalmazandó.34

Az értékbecslés - amellett, hogy nagyban befolyásolja a megtérülést -, tehát akkor tekinthető jogszerűnek, ha az a forgalmi érték figyelembe vételével történik, egyszersmind ok- és tényszerúek azon körülmények, amelyek az

27 Némiképp más a helyzet az adós által beszerzett magánszakértő szakvéleményével kapcsolatban [az igazságügyi szakértőkről szóló 2016. évi XXIX. törvény 52-53. \-ai]. A judikatúra az egyes eljárási jogágakban a magánszakértői véleményt generális jelleggel az ügyfél nyilatkozatának tekinti, figyelemmel arra, hogy a szakvélemény ezen esetekben az ügyfél által felkért - nem a hatóság által függetlenként kirendelt - szakértő szakmai álláspontja. A bizonyitékok értékelésének általános szabályai értelemszerủen a bizonyíték ezen formájára is vonatkoznak [Legfelsőbb Bíróság (Kúria) Gfv.V.31.286/1991., Pfv.VIII.20.256/1998., Pfv.II.21.840/2008., Pfv.VI.20.500/2011.].

${ }^{28}$ Legfelsőbb Bíróság (Kúria) Pfv.XI.21.908/2005., Kfv.III.35.245/2015.

29 Csiba Tibor: A szakértő szerepe a közigazgatási hatósági eljárásban és a közigazgatási bíráskodásban. Magyar Közigazgatás, 2005/2., 104-110.

${ }^{30}$ Legfelsőbb Bíróság (Kúria) Kfv.I.35.210/2008/5., Kfv.III.37.030/2013/6., Kfv.IV.37.730/2015/4.

${ }^{31}$ Kúria Kfv.V.35.186/2015/8., Kfv.I.35.356/2016.

32 „A forgalmi érték tehát a piac által elfogadott érték, általánosan bevett és elfogadott polgári jogi fogalom, ami elvileg egy dolog értékét (előnyös és hátrányos tulajdonságait) komplex módon értékeli a kereslet és kínálat összefüggésében.” [16/2017. (VII.10.) AB határozat].

${ }^{33}$ Kapa Mátyás: A kényszerértékesítések jellemző sajátosságai.

http://epa.oszk.hu/00800/00890/00060/EPA00890_polgari_szemle_2015_1-3_666.htm letöltés: 2019. május 1.

34 Kapa Mátyás: i.m. Ezen az állásponton van F. Kiss Gabriella és Pócza Judit is. F. Kiss Gabriella - Pócza Judit: Az ingatlanárverés mint kényszerértékesítési forma a magyar jogi szabályozásban; a hitelező árverési stratégiája. Themis, $2015 / 1$. 76-85. 
Debreceni Jogi Múhely 2019. (XVI.) 1-2.

Debreceni Egyetem, Állam- és Jogtudományi Kar, Polgári Jogi Tanszék, Debrecen

(University of Debrecen, Faculty of Law, Department of Civil Law, Debrecen)

DOI 10.24169/DJM/2019/1-2/2

értékelés során szerepet játszottak, illetőleg érvényesíti a fedezeti elvet is. Mindez nem szorítja háttérbe azon tényt, hogy jelentôs teret enged a szubjektumnak, ami a rendszer nem elhanyagolható kritikája. Ahogyan Pataki János István is utal arra, „A mérlegelés lehetőségének meghagyása már önmagában is automatikusan felvetheti a felelősség kérdését. A mérlegelési szabadság eljárási sokszínűséget okozhat, hiszen az egyén szubjektumához is jelentôs mértékben köthetô. A hatósági kényszercselekmények foganatosítása esetében kijelenthetô, hogy az egyedi megitélés lehetőségét a minimumra kell szorítani. Többek között a végrehajtó határozza meg egy ingó vagy ingatlan vagyontárgy forgalmi értékét a becsértéket, több esetben a belátására van bízva a zárgondnok alkalmazása (és költsége), helyszíni eljárás foganatosításakor ô dönti el, hogy mit von foglalás alá, egyes esetekben meghatározhatja az árverés (kényszerértékesítés) helyét és idejét, stb.”.35 Általánosságban egyet kell, hogy értsek ezen kijelentéssel. Ellenben megjegyzendő, hogy a megállapítás nemcsak az adóhatósági végrehajtók általi becsérték meghatározásban, hanem a szakvéleményben is szükségszerűen tükröződik; másrész pont ennek a kiküszöbölésére szolgál a becsérték - alábbiakban ismertetésre kerülő - korrigálásának a lehetősége.

Gyakorlati jogalkalmazói tapasztalatom alapján kijelenthetem, hogy az esetek többségében a végrehajtás alá vont vagyon árverésén kialakult ár erősen „nyomott ár”; azon kérdés eldöntéséhez pedig, hogy a kellő fedezet biztosítása végett foganatosított foglalás meddig terjedhet, az érintett vagyontárgyak keresleti-kínálati tapasztalataiból lehet, illetve kell kiindulni, figyelembe véve - a kényszerértékesítés sajátos térülési rátája miatt - a becsérték leszállításából elérhető eladási árat is.

\section{A becsérték korrekciója}

A jogszabály szerint - azon túl, hogy ha valamelyik fél kívánja, a végrehajtó a foglalásnál szakértő-becsüst alkalmaz - a foglalás után a végrehajtó szakértő-becsüs közremúködésével a becsértéket módosíthatja, ha ezt bármelyik fél a foglalási jegyzőkönyv kézbesítésétől számított 8 napon belül kérte [Vht. 97. \(3) bekezdése]. A szakértő és szakértő-becsüs közremúködésével összefüggésben felmerülő költségeket - amelyekre költségmentesség és költségfeljegyzési jog nem vehető igénybe - az köteles előlegezni, aki ezt az intézkedést kérte [Vht. 34. \(2) bekezdése].

Az Avt. is biztosít lehetőséget a becsérték korrekciójára; ingófoglalás esetén - ha az árverés sikertelen volt, vagy ha a becsérték megállapítása és az árverés között a végrehajtási eljárás szüneteltetése, felfüggesztése, igényper megindítása folytán legalább 3 hónap eltelt - az adóhatóság a becsértéket módosíthatja. Az adóhatóság módosítja a becsértéket az árverés közzétételéig akkor is, ha a becsérték megállapítása és az árverés közzététele között az értékesítendő ingóság forgalmi értékében jelentős változás állt be [Avt. 45. \-a].36 Ezen esetekben a korrekció hivatalból történik, indokát az árverés sikertelensége, a becsérték megállapítása után bekövetkezett - a jogszabályban rögzített feltételek valamelyikéhez köthető - időmúlás, vagy a vagyontárgy értékében bekövetkezett változás jelentheti. A becsérték módosításának irányait az Avt. nem adja meg; így lehetőség van a negatív irányú eltérítés mellett a becsérték magasabb összegben történő meghatározására is.

A kényszerértékesítés alatt is van lehetőség a kikiáltási ár - ami leképezi a becsérték összegét - leszállítására. Ingóságok esetén - fôszabály szerint - ha a felajánlott vételár nem éri el a kikiáltási árat, azt fokozatosan lejjebb kell szállítani, legfeljebb a becsérték $35 \%$-áig [Avt. 65. \(4) bekezdése]. Ingatlanok esetén a szabályozás némiképp más; az szerint a vételár a kikiáltási ár $50 \%$-áig szállítható le [Avt. 78. @ (2) bekezdése]. Speciális szabály vonatkozik a lakóingatlanokra; lakóingatlan esetén az árverési vételár legfeljebb a kikiáltási ár 75 \%-ának megfelelő összeg erejéig csökkenthető, feltéve, hogy az adósnak ez az egyetlen lakóingatlana, lakóhelye ebben van, és a végrehajtási eljárás megindítását megelőző 6 hónapban is ebben lakott [Avt. 84. \-a].37 A „negatív licit” lehetősége - a kikiáltási ár fokozatos leszállítása - akadályozza meg azt, hogy a vagyontárgyat - érvényes árajánlat hiányában - fel kelljen oldani a foglalás hatálya alól, hiszen ebben az esetben visszakerülne az adós rendelkezése alá, csökkentve a tartozás kielégítésére szolgáló vagyon értékét.

A becsértékkel szemben előterjesztett jogorvoslati kérelem esetén a felettes szerv eljárásának eredményeként

\footnotetext{
35 Pataki János István: i.m. 132.

${ }^{36}$ Ezen rendelkezések az ingatlanok becsértékének módosításával összefüggésben is alkalmazandóak [Avt. 54. \-a].

${ }^{37}$ Elektronikus árverés esetén ingóságoknál érvényes árverési ajánlatnak az árverés záró időpontjáig beérkezett, az ingóság becsértékének 50 \%-át elérő, vagy azt meghaladó 5 legmagasabb összegű ajánlat minősül. Ingatlanoknál a becsérték $65 \%$-át, lakóingatlan esetében a becsérték $75 \%$-át elérő vagy azt meghaladó összegű ajánlat tekinthető érvényesnek [Avt. 90. $\int(2)$ bekezdése, Avt. 91. \ (2) bekezdése].
} 
Debreceni Jogi Múhely 2019. (XVI.) 1-2.

Debreceni Egyetem, Állam- és Jogtudományi Kar, Polgári Jogi Tanszék, Debrecen

(University of Debrecen, Faculty of Law, Department of Civil Law, Debrecen)

DOI 10.24169/DJM/2019/1-2/2

szintén nyilhat mód a becsérték megváltoztatására. A becsérték közlésével szemben önálló jogorvoslatnak végrehajtási kifogásnak - van helye38. A végrehajtási kifogás a további cselekményekre halasztó hatályt főszabály szerint - nem jelent; ellenben a lefoglalt vagyontárgy értékesítése iránt csak az adott vagyontárgy foglalásával, becsértékének megállapításával szemben benyújtott végrehajtási kifogás végleges elbírálását követően lehet intézkedni [Avt. 27. \-a]. A becsérték közléssel szemben előterjesztett kifogások túlnyomórészt a becsérték összegszerűségét - jellemzően annak alacsony voltát - vitatják, ez azonban önmagában még nem szolgálhat alapul a már megállapított becsérték megváltoztatásához.

\section{A foglalási sorrend érvényesülése és annak korlátai}

Jóllehet az adóvégrehajtás során kötelező sorrendiség az egyes intézkedések (pénzforgalmi végrehajtás, ingó- és ingatlan végrehajtás) alkalmazási folyamatában főszabály szerint nincsen; ingatlanfoglalás foganatosítására akár már a végrehajtási eljárás megindításával egyidejúleg vagy azt követően bármikor sor kerülhet [Avt. 51. \-a]. Ugyanakkor az Avt. és a Vht. komplex rendszere rögzíti a szükségesség és arányosság elvének megfelelő irányvonalat akkor, amikor a foglalás, és a kényszerértékesítés menetében meghatározza az egyes cselekmények alkalmazásának korlátait, jellemzően a tartozás összegszerűségének, vagy a végrehajtás alá vont vagyoni elem (ingóság, ingatlan) függvényében. A szabályozás a teljeség igénye nélkül az alábbiakban foglalható össze:

A tartozást elsősorban átvezetéssel kell behajtani [Avt. 31. \(3) bekezdése]39. A 10.000 Ft-ot meg nem haladó nettó adótartozással rendelkező adós esetén az adóhatóság fizetési felhívást küld; egyébiránt az átvezetésen kívül más cselekményt nem foganatosít [Avt. 30. \(2) bekezdése]. Kis összegú követelés esetén az adóhatóság az átvezetésen kívül kizárólag hatósági átutalási megbízást (inkasszót) és jövedelemletiltást foganatosít; eredménytelenség esetén a tartozást ideiglenesen behajthatatlannak minősítheti és a végrehajthatóvá válásáig, vagy a végrehajtáshoz való jog elévüléséig ezen a jogcímen tarthatja nyilván [Avt. 21. §-a.].

200.000 Ft-ot nem meghaladó adók módjára behajtandó köztartozás esetén az adóhatóság csak inkasszót, illetve jövedelemletiltást foganatosít. Amennyiben ezt meghaladóan az adóst adótartozás is terheli, az adóhatóság egyéb cselekményeket is foganatosithat [Avt. 107. \-a].

A pénzkövetelést elsősorban a pénzforgalmi szolgáltatónál kezelt, az adós rendelkezése alatt álló összegból, az adós munkabéréből - a jogszabály szerint annak minősülő jövedelemből - kell behajtani [Vht. 7. 』 (1) bekezdése], ennek elöre látható eredménytelensége esetén az adós bármilyen lefoglalható vagyontárgya végrehajtás alá vonható [Vht. 7. \(2) bekezdése].

Nincs helye ingatlan-végrehajtásnak a természetes személy és az egyéni vállalkozó adós, valamint a vele együtt élő közeli hozzátartozók lakhatását közvetlenül szolgáló lakóingatlan esetén, ha a tartozás összege az 500.000 Ft-ot nem haladja meg [Avt. 52. \(1) bekezdése].

A lefoglalt ingatlant akkor lehet értékesíteni, ha a követelés egyéb végrehajtási cselekmény foganatosítása útján nem vagy csak aránytalanul hosszú idő múlva térülne meg [Avt. 59. S (1) bekezdése]. Ha az adóhatóság ingófoglalást és ingatlan-végrehajtást is foganatosított, az ingatlan értékesítése iránt akkor intézkedhet, ha az ingóság értékesítése eredménytelen volt, vagy a lefoglalt ingóságok értékesítéséből a tartozás előreláthatóan nem egyenlíthető ki, és a végrehajtási jog bejegyzésérôl szóló határozatnak az adóhatósággal való közlésétôl számított 45 nap vagy az ingatlan fekvése szerinti jegyző Vht. szerinti tájékoztatásának kézbesítésétől számított 60 nap már eltelt [Avt. 59. \$ (2) bekezdése].

Fenti szabályok komplexen, egymás mellett érvényesülnek, melyre tekintettel az egyes konkrét végrehajtási eszköz végrehajtó által történő megválasztása fokozott figyelmet igényel. Függetlenül tehát attól, hogy a jogalkotó a pénzforgalmi végrehajtást preferálja, a foglalás sorrendjének és terjedelmének meghatározása során a fedezeti elv bír jelentőséggel. A fedezeti elv, és a becsérték egymáshoz való viszonya amennyire szoros, annyira kényes; az adóvégrehajtónak olyan becsértéket kell kalkulálnia, mely lehetővé teszi a teljes követelés kielégítését (nem történik „alulfoglalás”), adósnak a legkevesebb sérelmet okozza, és a tartozáshoz mérve az arányosság követelményével (elkerülve a „túlfoglalást”) is összhangban áll. „Túlfoglalás” akkor merülhet fel, ha az adósnak

\footnotetext{
38 Avt. 24-27. \-ai.

${ }^{39}$ Ennek lényege, hogy ha az adóhatóság az adóst terhelő tartozás és eljárási költség mellett túlfizetést is nyilvántart, az átvezethető túlfizetés összegét az általa nyilvántartott tartozásokra elszámolhatja. A túlfizetés elszámolásával a tartozás a jóváirás napján a jóváírás összegével megfizetettnek minősül [Avt. 32. \(1)-(3) bekezdései].
} 
Debreceni Jogi Múhely 2019. (XVI.) 1-2.

Debreceni Egyetem, Állam- és Jogtudományi Kar, Polgári Jogi Tanszék, Debrecen

(University of Debrecen, Faculty of Law, Department of Civil Law, Debrecen)

DOI 10.24169/DJM/2019/1-2/2

több végrehajtás alá vonható vagyontárgya van; a végrehajtónak addig kell a foglalást folytatnia, amíg elegendő fedezetet nem teremt a követelésre. A behajtáshoz tehát olyan eszközt kell választani, mely az adós vagyoni viszonyait csak a behajtáshoz szükséges mértékben érinti; az állami kényszer elsődlegesen az adós vagyoni jogait korlátozza, csak kivételesen érintheti a személyiségi jogait.40

\section{Néhány gondolat a fedezetcseréről}

Jóllehet a törvény szabályozza mind a végrehajtási eljárás felfüggesztésének [Avt. 15. \-a], mind a végrehajtási eljárás szünetelésének [Avt. 16. §-a] eseteit, előfordulhatnak olyan élethelyzetek, amelyekben - bár sem a felfüggesztés, sem pedig a szünetelés feltételei nem állnak fenn - az adós körülményei méltányos eljárást igényelnek az adóhatóság részéről. Ezen szituációk megoldására ad lehetőséget a fedezetcsere jogintézménye, mely a jogszabályi célnak eleget téve úgy teljesíti az adóvégrehajtással szemben támasztott alapelveket, hogy egyensúlyt teremt mind az adóhatóság - mint végrehajtó, és hitelező -, mind pedig az adós érdekei között. Az adóhatóság adós méltánylást érdemlố körülményére tekintettel - legkésőbb az árverés kitűzését megelőzően előterjesztett kérelmére a lefoglalt ingó vagyontárgyat feloldja a foglalás alól, ha a tartozás megtérülése a feloldást követően is biztosított, illetve abban az esetben, ha az adós olyan vagyontárgyat ajánl fel a tartozás fedezetéül, amely a feloldani kért vagyontárgy piaci értékét eléri, vagy azt meghaladja. A vagyontárgy feloldására és a felajánlott vagyontárgy lefoglalására egyidejúleg kerül sor [Avt. 50. \(1) bekezdése]. A joghely első fordulata az esetleges „túlfoglalás” orvoslására hivatott, ez esetben a fedezeti érték tényleges csökkentésére kerül sor; míg a második fordulata rendelkezik arról, amikor egy lefoglalt ingóság helyett egy másik, ugyancsak forgalomképes vagyontárgyat vonnak a fedezeti körbe, ez esetben a fedezeti érték - legalábbis negatív irányban - nem változik.

A jogszabályhely alkalmazásának egyik feltétele tehát az adós által előterjesztett - indokolt, és bizonyítékokkal alátámasztott - kérelem, mely előterjesztési határidő kötött; annak végső időpontja az árverés kitűzése. Az adóhatóság a lefoglalt ingóság értékesítése iránt a foglalást, illetve a vízi, légi jármú lajstromának, valamint az egyedi azonosításra kétséget kizáróan alkalmas ingó dologként jogszabályban meghatározott vagyontárgy foglalása esetén a zálogjogi nyilvántartás adatainak beszerzését követô 30 nap eltelte után, 8 napon belül intézkedik [Avt. 58. \(1) bekezdése].41

A különös méltánylást érdemlő körülményt az Avt. nem definiálja, még exemplifikatív módon sem. Ezt azért lényeges, mert csak a kérelem és az azt alátámasztó bizonyítékok alapján kerülhet az adóhatóság azon helyzetbe, hogy a kérelem teljesítését az eset körülményei és a rendelkezésére álló adatok alapján mérlegelje, és ennek eredményeként hozza meg döntését. Támpontot jelenthetnek a végrehajtás felfüggesztésére indokot adó körülmények; az adós tartási kötelezettségébe tartozó személyek száma, az adós vagy az eltartott személy tartós és súlyos betegsége, az adóst is sújtó, a végrehajtás során bekövetkezett elemi csapás vagy ipari katasztrófa [Avt. 15. \(4) bekezdése].

A harmadik törvényi feltétel a végrehajtás alá vont ingóért egy harmadik vagyontárgy csereként történő felajánlása. A jogszabály ingóság esetén nyújt lehetôséget a fedezet cseréjére [Avt. 50. \(1) bekezdése], ellenben visszautal ezen jogszabályhelyre [Avt. 55. \-a], amely szerint a szabályozás az ingatlan-végrehajtással összefüggésben is megfelelően alkalmazandó azzal, hogy foglaláson ebben az esetben az adós ingatlanának jelzáloggal történő megterhelését is érteni kell. Úgyszintén kérdés az, hogy mi lehet a fedezetcsere tárgya. Törvény eltérő rendelkezése hiányában lényegében minden olyan dolog, ami forgalomképes, pénzben kifejezhető értékkel bír, és - jóllehet a törvény expressis verbis nem rögzíti - az új fedezettel szemben a lefoglalás általános feltételei fennállnak. Utóbbi levezethetô a jogszabályhely második mondatából, mely szerint a vagyontárgy feloldására és a felajánlott vagyontárgy lefoglalására egyidejűleg kerül sor. Mindez - a Vht. 86. \(1) bekezdésével, valamint a 136. \-ával való komplex értelmezésben, negatív megközelítésben - egyszersmind azt is jelenti, hogy nem vonható az adóssal szemben folytatott végrehajtás körébe a tulajdonos esetleges hozzájárulásától függetlenül

\footnotetext{
40 Avt. 35. S (2) bekezdése, 1252/B/2010. AB határozat.

41 A jogszabály az értékesítés végső határidejét objektív módon is meghatározza - 3 hónap -, az árverés kitűzését a végrehajtóra bízza olyan időpontra, amely a helyi körülmények között a legcélszerúbb [Avt. 58. \ (3) bekezdése]. Az ingatlan értékesítésére - az egyéb feltételek fennállása esetén - akkor kerülhet sor, ha a végrehajtási jog bejegyzéséről szóló határozatnak az adóhatósággal való közlésétől számított 45 nap vagy az ingatlan fekvése szerinti jegyző Vht. szerinti tájékoztatásának kézbesítésétől számított 60 nap már eltelt [Avt. 59. \(2) bekezdése]. Az értékesítés határidejét - az objektív 3 hónapon belül - a törvény az ingósághoz hasonlóan rögzíti [Avt. 59. \(4) bekezdése]. Az igényper az ingóság, és az ingatlan árverése vonatkozásában is halasztó hatályú [Avt. 58. \ (2) bekezdése, Avt. 59. \(3) bekezdése].
} 
azon vagyontárgy, amely bizonyítottan nem áll az adós tulajdonában. Bár a törvényhely csak a feltételek konjunktív megléte esetén alkalmazható, ha a felajánlani kívánt új fedezettel kapcsolatosan a szövegértelmezésből álláspontom szerint kikövetkeztethető tulajdonosi minőség, mint alapfeltétel hiányzik, az ezen hiányosságon túli elemek - a különös méltánylást érdemlő körülmény fennállása, a felajánlani kívánt vagyontárgy forgalmi értékének a tartozáshoz viszonyított aránya, valamint az azt befolyásoló egyes tényezók - vizsgálatára nem is kerülhet sor. A törvény is rendelkezik korlátozó szabályokról, amikor egyes vagyonelemek esetén egyrészt a foglalás lehetőségét kizárja42, másrészt az Avt. 50. \(3) bekezdése a fedezetcsere intézményét szorítja korlátok közé [Avt. 50. \(3) bekezdése. Eszerint fedezetcsere során az 52. \(1) bekezdése nem alkalmazandó; vagyis nincs helye ingatlan-végrehajtásnak a természetes személy és az egyéni vállalkozó adós, valamint a vele együtt élő közeli hozzátartozók lakhatását közvetlenül szolgáló lakóingatlan esetén, ha a tartozás összege az 500.000 Ft-ot nem haladja meg.]. Harmadrészt a normakörnyezet explicit csak az ingóság foglalás hatálya alól való feloldásának lehetőségét rögzíti; a már lefoglalt ingatlan kapcsán a jogintézmény alkalmazása így csupán elvi síkon értelmezhető.

Amíg a végrehajtás felfüggesztése, és a szünetelése alatt a végrehajtási cselekmények kapcsán fennáll a moratórium, mindez nem vonatkozik a fedezetcserére; arra a végrehajtás megakasztásának folyamatában is sor kerülhet [Avt. 50. \(2) bekezdése].

A kérelem alapján az adóhatóság végzéssel dönt [Air. 72. \és 73. \(1) bekezdése], melyben - a kérelemnek helyt adó döntés esetén - a végrehajtás alá vont vagyontárgynak a foglalás hatálya alól történô feloldása, és az új fedezet lefoglalása iránt is intézkednie kell. A végzés ellen az Avt. 28. \(1) bekezdésének a) pontja alapján önálló fellebbezésnek van helye.

Jóllehet jelentôs jogalkalmazói tapasztalatokról korai beszélni, az új jogintézménnyel lazultak az adóvégrehajtás kötöttségei, egyszersmind azt sugallják, hogy az adóhatóságnak az eredményes adóvégrehajtást szem előtt tartva már méltányossági szempontokat is indokolt figyelembe vennie, mellyel közvetett módon a jogkövetó magatartásra való ösztönzés is elérhető. Mindez eleme lehet az adóhatóság által az elmúlt időszakban hangoztatott „szolgáltató jellegnek”.43

\section{Zárszó}

Értekezésem végkövetkeztetése az, hogy a fedezeti elv, és a becsérték közötti korreláció nem vitatható, mi több, lényegében szükségszerűnek tekinthető. A kettő közötti kapcsolat irányt ad az adótartozás behajtásának folyamatában, ahogy behatárolhatja a térülés érdekében foganatosítandó cselekményeket is. Reményeim szerint sikerült megvilágítani, hogy a becsérték megállapítása nem pusztán mechanikus jogalkalmazói aktus, az a bizonyítékok gondos értékelését igénylő múvelet; az ennek alkalmával számszerűsített érték az adóvégrehajtás menetét is befolyásolhatja. Ugyanakkor fenntartom a véleményemet abban a körben, miszerint a becsérték megállapítása nem tekinthető olyan szakkérdésnek, amely a végrehajtási eljárás során ab ovo igényelné az igazságügyi szakértő közremúködését. Mindez természetesen nem annulálja azon kijelentést, mely szerint a becsérték megállapítása során az adóhatóságot fokozott felelősség terheli. Az adóhatóság eljárását ugyanis szükségképp jellemzi azon - általam napi szinten tapasztalt - kettőség, mely egyrészt a végrehajtást kérő - az állam, mint hitelező - jogait is védi, másrészt az adósi garanciák érvényre juttatásával igyekszik ellenőrizhetővé tenni a behajtásra irányuló intézkedések folyamatát. Dolgozatomat az általam már többször hivatkozott Alkotmánybíróság soraival zárom. „...A jogállami keretek között múködő végrehajtási jog célja nem az adós ellehetetlenítése, hanem az, hogy lehetőséget nyújtson arra, hogy a kötelező erejú hatósági határozatban foglaltaknak a legegyszerűbb, leggyorsabb és leghatékonyabb módon érvényt lehessen szerezni. Ennek megfelelően a végrehajtási jognak kellő egyensúlyokat és garanciákat szükséges tartalmaznia ahhoz, hogy mind az adós, mind a végrehajtást kezdeményező érdeke megfelelóen érvényesülhessen, illetve a téves vagy törvénysértő

42 A Vht. 90-96/B. \-ai. Végrehajtás alól mentességet élvező vagyontárgyakra kényszerintézkedés még adós esetleges beleegyezése esetén sem foganatosítható [Vht. 89. \(1) bekezdése].

43 Az Avt. 50. \-ához füzött törvényalkotói indokolás szerint a törvény „...új, de a gyakorlati tapasztalatokon alapuló, ügyfélbarát jogintézményt honosít meg a közigazgatási végrehajtásban a fedezetcsere szabályozásával. A hatóság oldaláról rugalmasságot nem engedő korábban hatályos szabályozás alapján ugyanis nem volt lehetőség a lefoglalt vagyontárgy végrehajtás alól történô feloldására, még abban az esetben sem, ha a cserében felajánlott vagyontárgy értéke a lefoglalt vagyontárgy értékét eléri vagy azt meghaladja, illetve ha a tartozás összegének csökkenése miatt az adott vagyontárgy végrehajtás alóli feloldása miatt a végrehajtás célja nem kerülne veszélybe.”. 
Debreceni Jogi Múhely 2019. (XVI.) 1-2.

Debreceni Egyetem, Állam- és Jogtudományi Kar, Polgári Jogi Tanszék, Debrecen

(University of Debrecen, Faculty of Law, Department of Civil Law, Debrecen)

DOI 10.24169/DJM/2019/1-2/2

végrehajtási cselekmények megelőzhetőek, kiküszöbölhetők és hatékonyan orvosolhatóak legyenek.”.44 Az adóvégrehajtás jelenlegi szabályozása ennek - álláspontom szerint - eleget tesz, mely kijelentést helytállónak érzem a címben jelzett jogintézmények gyakorlatban történő érvényesülésére is.

Felhasznált irodalom:

Csiba Tibor: A szakértő szerepe a közigazgatási hatósági eljárásban és a közigazgatási bíráskodásban. Magyar Közigazgatás, 2005/2., 104-110.

F. Kiss Gabriella - Pócza Judit: Az ingatlanárverés mint kényszerértékesítési forma a magyar jogi szabályozásban; a hitelező árverési stratégiája. Themis, 2015/1. 76-85.

Juhász Eszter: A végrehajtási kifogás új szabályainak margójára. Jog-Állam-Politika 2012/3. 131-142.

Kálmán János: A szakkérdés vizsgálata a magyar közigazgatási hatósági eljárásjogban. Jogtudományi Közlöny, 2018/2. 104-113.

Kapa Mátyás: A kényszerértékesítések jellemző sajátosságai. Polgári Szemle, 2015/1-3. http://epa.oszk.hu/00800/00890/00060/EPA00890_polgari_szemle_2015_1-3_666.htm

Kapa Mátyás: A kényszereljárások eredménytelensége - okok és következmények. Gazdasági Élet és Társadalom. 2012/1-2., 98-107.

Pataki János István: Gondolatok a bírósági végrehajtás rendszeréről. Jogelméleti Szemle, 2013/1. 121-135.

Schadl György: Az ingófoglalás alapvető szabályai a bírósági végrehajtás során. Polgári Szemle, 2017/1-3., 83-93. https://doi.org/10.24307/psz.2017.0908

Jogszabályok jegyzéke:

Magyarország Alaptörvénye

az adóhatóság által foganatosítandó végrehajtási eljárásokról szóló 2017. évi CLIII. törvény

az adóigazgatási rendtartásról szóló 2017. évi CLI. törvény

az adózás rendjéről szóló 2017. évi CL. törvény

a bírósági végrehajtásról szóló 1994. évi LIII. törvény

az illetékekről szóló 1990. évi XCIII. törvény

a Büntető Törvénykönyvről szóló 2012. évi C. törvény

az igazságügyi szakértőkről szóló 2016. évi XXIX. törvény

Legfelsőbb Bíróság - Kúria - döntéseinek jegyzéke:

Gf.I.32.354/2002.

Gfv.V.31.286/1991.

Kfv.35.186/2015/8.

Kfv.35.356/2016.

Kfv.I.35.210/2008/5.

Kfv.I.35.270/2017.

Kfv.I.35.770/2016/9.

Kfv.II.39.070/2005.

Kfv.III.35.103/2015/17.

44 22/2013. (VII.19.) AB határozat. 
Debreceni Jogi Múhely 2019. (XVI.) 1-2.

Debreceni Egyetem, Állam- és Jogtudományi Kar, Polgári Jogi Tanszék, Debrecen

(University of Debrecen, Faculty of Law, Department of Civil Law, Debrecen)

DOI 10.24169/DJM/2019/1-2/2

Kfv.III.35.245/2015.

Kfv.III.37.030/2013/6.

Kfv.III.37.054/2010.

Kfv.IV.37.730/2015/4

Kfv.V.35.789/2014/4.

Kfv.V.37.437/2000.

Pfv.I.20.212/1999.

Pfv.I.21.372/2015.

Pfv.I.22.365/1999.

Pfv.II.21.840/2008.

Pfv.VI.20.500/2011.

Pfv.VIII.20.256/1998

Pfv.XI.21.908/2005

Alsóbb szintű bíróságok döntéseinek jegyzéke:

Fővárosi Ítélőtábla 16.Cgf.43.336/2006.

Fővárosi Ítélótábla 13.Cgf.47.070/2018/2.

Debreceni Ítélőtábla Pf.II.20.262/2008.

Alkotmánybírósági döntések (határozatok, végzések) jegyzéke:

a bírósági végrehajtástól szóló 1994. évi LIII. törvény 34/A. 『-a alkotmányellenességének vizsgálatáról szóló 1252/B/2010. AB határozat

az adózás rendjéről szóló 2003. évi XCII. törvény 152. \(1) bekezdése „a végrehajtható okirat csatolása nélkül” szövegrésze alaptörvény-ellenességének megállapítására és megsemmisítésére irányuló indítvány elutasításáról szóló 22/2013. (VII.19.) AB határozat

a bírósági végrehajtásról szóló 1994. évi LIII. törvény 6. (1) bekezdése alkotmányellenességének vizsgálatáról szóló 539/D/2005. AB határozat

3090/2019. (V.7.) AB határozat

241/D/2010. AB határozat

56/1991. (XI.8.) AB határozat

419/E/2000. AB határozat

3119/2016. (VI.21.) AB végzés

16/2017. (VII.10.) AB határozat

7/1991. (II.28.) AB határozat

11/1993. (II.27.) AB határozat

7/2013. (III.1.) AB határozat 